\title{
Serum levels of interleukin-6 in contacts of active pulmonary tuberculosis
}

\author{
Niveis séricos de interleucina-6 em contatos de tuberculose pulmonar ativa
}

Fernando Henrique Azevedo Lopes' ${ }^{1}$ Lívia Coelho de Assis²; Roberto da Justa Pires Neto ${ }^{3}$; Karine Paschoal Botelho Kélvia Miranda Sá́; Cristiane Cunha Frota ${ }^{6}$; José Walter Correia ; Max Victor Carioca Freitas ${ }^{8}$

\begin{abstract}
Introduction: It is estimated that over two billion individuals are infected by Mycobacterium tuberculosis worldwide. Interleukin-6 (IL6) is an important cytokine whose serum levels are commonly high in active pulmonary tuberculosis (TB). IL-6 screening in contacts of patients with TB may be useful to monitor the progress of the infectious process and to infer the risk of progression to active disease. Objective: To evaluate the serum levels of interleukin- 6 in contacts of patients with active pulmonary tuberculosis and to compare them with two other groups: a) patients affected by active pulmonary tuberculosis; b) non-contacts of tuberculosis. Methods: Cross-sectional study with 15 contacts of patients with active pulmonary tuberculosis, selected according to the protocol recommended by the Ministry of Health. The serum levels of interleukin- 6 were measured by Enzyme-linked immunosorbent assay (ELISA). The same test was also applied in the two comparison groups: 38 patients with active pulmonary tuberculosis (confirmed by clinical examination, X-rays of the chest and baciloscopy) and 63 non-contacts (healthy blood donors). Results: In the contact group, the median IL-6 concentration was 1.7 pg/ $\mathrm{ml}(0.96-4.8 \mathrm{pg} / \mathrm{ml})$. For those affected by active pulmonary tuberculosis and non-contact individuals, these values corresponded to 4.3 $\mathrm{pg} / \mathrm{ml}(0.5-24 \mathrm{pg} / \mathrm{ml})$ and $0.5 \mathrm{pg} / \mathrm{ml}(0-2.8 \mathrm{pg} / \mathrm{ml})$, respectively $(\not<0.0001)$. Conclusion: Contacts of patients with active pulmonary tuberculosis had significantly higher IL-6 serum levels (3.4 times higher) in relation to non-contact individuals, but on a lower level (2.5 times lower) when compared to those affected by active disease.
\end{abstract}

Key words: Mycobacterium tuberculosis; latent tuberculosis; tuberculosis; interleukin-6; enzyme-linked immunosorbent assay.

\section{INTRODUCTION}

Tuberculosis remains a major challenge to public health worldwide. It is estimated that one out of every three humans is infected with its etiologic agent, Mycobacterium tuberculosis (M. $t b)^{(1,4)}$. Although there have been effective drugs for over 50 years, every 15 seconds someone dies of tuberculosis worldwide, and each second there is a new case of infection by M. $t b^{(5)}$. Epidemiological data show that in 2010, the incidence rate of TB in Ceará was 43 cases per 100,000 inhabitants, which was higher than the national average, accounting for 37.7 cases per 100,000 inhabitants in the same year ${ }^{(15)}$.

Although there are numerous studies in the scientific literature about the immunopathogenesis of tuberculosis in its active form, there are few investigations focusing on the latent $\mathrm{M}$. $t b$ infection

First submission on 21/12/12; last submission on 20/08/13; accepted for publication on 12/09/13; published on 20/12/13

1. MSc in Pathology by Universidade Federal do Ceará-School of Medicine (UFC); professor of immunology and Pathology at Faculdade de Tecnologia Intensiva (Fateci)

2. Pharmacist.

3. Doctor; adjunct professor at the Community Health Department-UFC-School of Medicine; doctor at the Tuberculosis Outpatient Clinic from Hospital São José de Doenças Infecciosas.

4. Graduate medical student at UFC.

5. Pharmacist; specialist in Microbiology, Clinical Analysis and Hospital Pharmacy; technician at the Immunology Laboratory from the Pathology and Legal Medicine

Department - UFC.

6. PhD in Mycobacterium by University College London-National Institute for Medical Research, England; associate professor I at UFC.

7. Doctor in Medical Sciences by UFC; doctor at Hospital Geral Dr. César Cals.

8. Doctor in Medical Clinic by Universidade de São Paulo (USP); adjunct professor of Immunology at UFC-School of Medicine. 
(LTBI). This condition is asymptomatic, non-transmissible, and presupposes the absence of clinical or radiological evidence of the disease, although there are viable bacilli in the tissues. This scarcity of studies may be partly due to the difficulty in identifying LTBI accurately and unequivocally. To date, the diagnostic approach has been based on positive tuberculin test (TT) or interferon-gamma release assays (IGRAs) ${ }^{(11,18)}$. These methods, however, are unable to distinguish latent infection from active disease, inasmuch as they only indicate an immunologic sensitization due to prior exposure to $\mathrm{M}$. $t b$ antigens. Both are inaccurate in confirming the presence of viable bacilli( ${ }^{(12,21)}$.

Tuberculosis control lies in early identification and prophylactic treatment of healthy individuals infected with M. $t b$ who are at imminent risk of progression to active disease ${ }^{(12)}$.

In most individuals infected with M. $t b$, the immune system is able to maintain the bacillus under control, although it does not eliminate it altogether. Among individuals exposed to $\mathrm{M}$. $t b$ and those who developed an adaptive immune response to it, hence considered affected by LTBI, only a small proportion (about $5 \%$ ) will evolve into the active form of the disease within $2-5$ years. $95 \%$ will remain free of the active disease unless they become immunocompromised, namely in the case of co-infection with human immunodeficiency virus (HIV) or undergoing immunosuppressive treatment ${ }^{(3)}$.

The control of M. $t b$ by the immune system is founded on a typical cellular response that is triggered in most individuals by the hypersensitivity reaction mediated by $\mathrm{T}_{H} 1$ lymphocytes within 2-10 weeks after infection ${ }^{(8,9,22)}$. This reaction depends on the integrated action of several cytokines such as interleukin-12 (IL-12), IFN- $\lambda$, tumor necrosis factor alpha (TNF- $\alpha$ ) as well as reactive nitrogen and oxygen intermediates. The combined actions of these substances promote the destruction of bacilli previously phagocytosed by infected macrophages ${ }^{(3,7,9,13)}$.

Interleukin-6 (IL-6) has been noted for having a relevant role in the immunopathogenesis of tuberculosis. For instance, it is known for stimulating the secretion of IFN-gamma, a crucial cytokine in the activation of macrophages infected with M. Tb, although the precise mechanism of such interaction still requires further clarification ${ }^{(10,19)}$.

\section{OBJECTIVE}

The present study had the objective to determine IL- 6 blood levels in contacts of patients with active pulmonary tuberculosis and compare them with non-contact individuals as well as patients with the active disease.

\section{METHODS}

\section{Research subjects}

The test group comprised 15 contacts of patients with active pulmonary tuberculosis, who aged between 15 and 81 years and were diagnosed through clinical examination, radiography and pulmonary smear. They were admitted at Hospital São José de Doenças Infecciosas (HSJ) and at Centro de Saúde da Família Anastácio Magalhães (CSFAM) in Fortaleza, Ceará, Brazil. The definitions of contact and LTBI adopted herein were those recommended by the Ministry of Health (MH) ${ }^{(14)}$. Thus, asymptomatic individuals who lived with the index case at the time of diagnosis of active pulmonary tuberculosis were considered contacts. This interaction could occur at home and/or work environments, long-stay institutions, school and kindergarten. In accordance with $\mathrm{MH}$, contacts that presented TT $\geq 5 \mathrm{~mm}$ and a normal chest x-ray were considered LTBI. When TT result was < $5 \mathrm{~mm}$, subjects were advised to return after eight weeks in order to repeat the test. Thus, those who presented TT alterations were also considered LTBI. An increase of at least $10 \mathrm{~mm}$ in induration in comparison with the previous TT was regarded as conversion.

One hundred and one subjects who had participated in a previous study carried out by the same research group were also included in the present investigation ${ }^{(2)}$, which was stratified into two subgroups:

1) healthy non-contacts - 63 voluntary blood donors from the Center for Hematology and Hemotherapy of Ceará, Brazil (Hemoce), with no previous reports of tuberculosis or contact with patients with tuberculosis, according to data collected from a questionnaire; 2) thirty-eight patients with active pulmonary tuberculosis (TB group) confirmed by positive sputum culture, coming from Hospital de Messejana, Hospital de Maracanaú and Hospital Geral Dr. César Cals, Fortaleza, Ceará, Brazil.

\section{Determination of IL-6}

The serum concentrations of IL-6 in peripheral venous blood were assessed by an enzyme immunoassay (ELISA), according to guidelines provided by Invitrogen Corporation (Frederick Maryland, USA), which supplied the kit.

\section{Statistical Analysis}

The Mann-Whitney and Kruskal-Wallis tests were used to compare IL-6 serum concentrations. The Shapiro-Wilkinson test was applied to assess the normality of the assessed samples. The level of statistical significance was set to $\mathrm{p}$ values lower than 0.05 . 


\section{Ethical considerations}

This study was approved by the Ethical Research Committees (Comitê de Ética em Pesquisa [CEP]) from the University Hospital Walter Cantídio (Protocol 125.12.10) and HSJ (Protocol 032/2011). All study subjects signed an Informed Consent Form (ICF). Both ERCs agreed that the project was in accordance with resolution 196/96 of the National Health Council (CNS), which regulates research involving human subjects in Brazil.

\section{RESULTS}

\section{Demographic data}

The demographic characteristics of the contact groups and of both comparison groups are shown in Table.

\begin{tabular}{|c|c|c|c|}
\hline \multicolumn{4}{|c|}{$\begin{array}{c}\text { TABLE - Demographic characteristics of contacts of patients } \\
\text { with active pulmonary tuberculosis and non-contacts }\end{array}$} \\
\hline $\begin{array}{c}\text { Demographic } \\
\text { characteristics }\end{array}$ & $\begin{array}{c}\text { Contacts } n(\%) \\
(n=15)\end{array}$ & $\begin{array}{c}\text { TB } n(\%) \\
(n=38)\end{array}$ & $\begin{array}{c}\text { Non-contacts } n(\%) \\
(n=63)\end{array}$ \\
\hline Male & $03(20)$ & $25(65,8)$ & $51(81)$ \\
\hline Female & $12(80)$ & $13(34,2)$ & $12(19)$ \\
\hline $\begin{array}{c}\text { Median age } \\
\text { (min-max) }\end{array}$ & $45(15-81)$ & $\begin{array}{c}44(20- \\
70)\end{array}$ & $26(19-50)$ \\
\hline
\end{tabular}

\section{IL-6 concentrations}

The median of IL- 6 serum levels was $1.7 \mathrm{pg} / \mathrm{ml}$ (0.96 to $4.8 \mathrm{pg} / \mathrm{ml}$ ) in the test group (contacts). As to the comparison groups, the median IL-6 concentration levels were $4.3 \mathrm{pg} / \mathrm{ml}$ $(0.5-24 \mathrm{pg} / \mathrm{ml})$ and $0.5 \mathrm{pg} / \mathrm{ml}(0$ to $2.8 \mathrm{pg} / \mathrm{ml})$ for TB subgroups and non-contacts, respectively. There was statistical significance $(p<0.0001)$ when the three groups were contrasted. These data are shown in Figure.

\section{DISCUSSION}

IL-6 is a pleiotropic cytokine that performs several pathophysiological functions in humans ${ }^{(17)}$. Produced by a variety of cells such as mononuclear phagocytes, fibroblasts, endothelial cells, T and B lymphocytes, among others, IL-6 plays a major role in stimulating the synthesis of acute-phase proteins, mainly C-reactive protein, in response to various stimuli ${ }^{(6)}$.

In active pulmonary tuberculosis, the present investigation demonstrated that blood levels of IL-6 were significantly higher in patients (8.6 times) in contrast with healthy controls ${ }^{(2)}$.

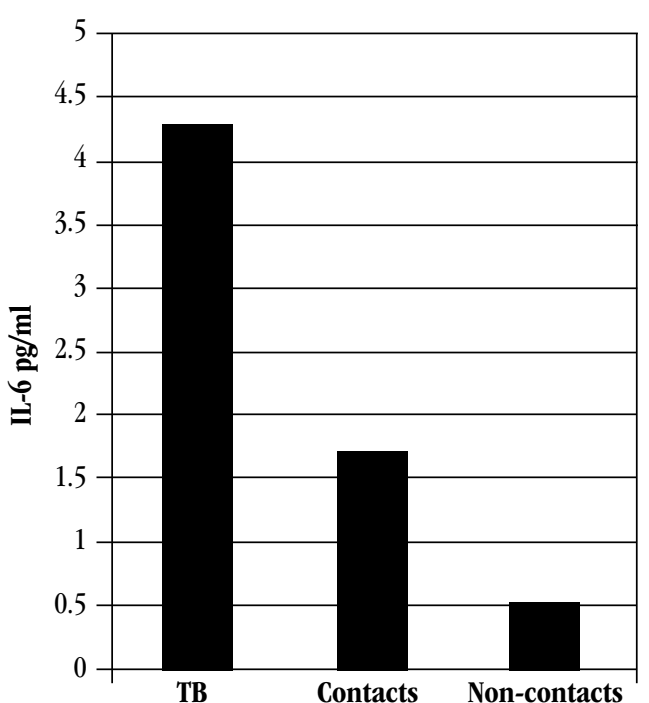

FIGURE - IL-6 serum levels in contact, TB and non-contact groups Values are presented in median. The variations $(\mathrm{pg} / \mathrm{ml})$ were $T B=0.5-24$, contacts $=0.96-4.8$ and non-contacts $=0-2.8 . p<0.0001$ when the three groups were contrasted.

TB: pulmonary tuberculosis

Nevertheless, the exact role of this cytokine in tuberculosis has proved to be controversial.

IL-6 secreted by macrophages infected with M. $t b$ is able to inhibit the response to INF- $\lambda$ by non-infected macrophages adjacent to infected ones ${ }^{(16)}$. These results reveal that IL-6 may be involved in the inability of the cellular immune response to eradicate the infection. This cytokine can also be harmful to mycobacterial infections, insofar as it is able to inhibit the production of TNF- $\alpha$ and interleukin-1 beta (IL-1 $\beta)^{(20)}$. It is possible that high concentrations of IL- 6 , as observed in active pulmonary $\mathrm{TB}$, may contribute to the disease progression, whereas intermediate concentrations found in contacts could contribute to the maintenance of the latent state.

On the other hand, there are studies that suggest that IL-6 has a protective role in relation to M. $t b$. Murines with deficiency in IL-6 production are more susceptible to infection by M. $t b$. Furthermore, IL-6 gene knockout mice have lower IFN- $\lambda$ production, which plays a crucial role in the protective response to M. $t b^{(10)}$. Thus, according to the data obtained herein, it can be concluded that IL-6 serum levels in contact group were insufficient to promote the neutralization of cytokines (particularly TNF- $\alpha$ ), which are involved in the formation or development of granuloma.

IL-6 serum levels were measured and compared in the three analyzed groups. For the contacts, the concentration was 3.4 times 
higher in comparison with non contacts $(1.7 \mathrm{pg} / \mathrm{ml} \times 0.5 \mathrm{pg} / \mathrm{ml})$ and 2.5 times lower in comparison with the active pulmonary TB group $(1.7 \mathrm{pg} / \mathrm{ml} \times 4.3 \mathrm{pg} / \mathrm{ml})$. According to the MS guidelines, the contacts underwent a tuberculin test and the reactive ones were included in this study as latent infection. Accordingly, it can be hypothesized that IL-6 production levels play a role in the maintenance of latent state. The concentrations were determined by ELISA, but the kits used to assess the contacts and to evaluate patients and health individuals were from different suppliers. However, data were considered comparable due to the fact that both kits Biosource (patients and controls) and Invitrogen (contacts) have similar performance characteristics.

Considering that the antigenic stimulus for cytokine production is the infection by M. tb and taking into account the above data, we can assume that the production of IL-6 is directly proportional to the bacterial load. Furthermore, the rise in serum IL-6 may be related to the progression of the infection process. To date, this research group knows no other studies that have investigated IL-6 serum levels in contacts of patients with active pulmonary tuberculosis.

\section{CONCLUSION}

The present study demonstrates that the production of IL-6 is higher in both groups: patients with TB and contacts of active pulmonary TB. Moreover, its production is exacerbated in the first group. Furthermore, non-contact individuals, hence with no antigenic challenge by M. $t b$, produced significantly lower amounts of IL-6. Future studies are required to confirm these data and their potential clinical applications.

\section{FUNDING}

Development Coordination of Higher Education Personnel (Coordenação de Aperfeiçoamento de Pessoal de Nível Superior [CAPES]),

\section{RESUMO}

Introdução: Estima-se em mais de dois bilhões o número de infectadospelo Mycobacterium tuberculosis no mundo. A interleucina-6 (IL-6) é uma importante citocina, cujos niveis séricos estão comumente elevados na tuberculose pulmonar ativa. A dosagem dessa citocina em contatos de pacientes com tuberculose pode ser útil para se acompanhar a evolução do processo infeccioso, bem como para inferir o risco de progressão da doença ativa. Objetivo: Avaliar os niveis séricos de IL-6 em contatos de pacientes com tuberculose pulmonar ativa e compará-los com os de dois outros grupos: a) pacientes acometidos por tuberculose pulmonar ativa; b) não contatos de tuberculose. Métodos: Estudo transversal com 15 contatos de pacientes com tuberculose pulmonar ativa, selecionados de acordo com protocolo preconizado pelo Ministério da Saúde. Os niveis séricos de IL-6 foram mensurados por meio de ensaio imunoenzimático (ELISA). 0 mesmo ensaio também foi empregado nos dois grupos de comparação: 38 pacientes com tuberculose pulmonar ativa (confirmada por exame clínico, raios $X$ de tórax e baciloscopia) e 63 não contatos, doadores saudáveis de sangue. Resultados: Para o grupo de contatos, a mediana de concentração de IL-6 foi de 1,7 pg/ml (0,96-4,8 pg/ $\mathrm{ml})$; para os acometidos por tuberculose pulmonar ativa e indivíduos não contatos, esses valores foram $4,3 \mathrm{pg} / \mathrm{ml}(0-12 \mathrm{pg} / \mathrm{ml})$ e 0,5 pg/ml $(0-2,8 \mathrm{pg} / \mathrm{ml})$, respectivamente $(\mathrm{p}<0,0001)$. Conclusão: Contatos de pacientes com tuberculose pulmonar ativa apresentaram niveis séricos de IL-6 significativamente aumentados (3,4 vezes mais), em relação aos indivíduos não contatos, mas em um patamar inferior (2,5 vezes menos), quando comparados com os acometidos pela doença ativa.

Unitermos: Mycobacterium tuberculosis; tuberculose latente; tuberculose; interleucina-6; ensaio de imunoadsorção enzimática.

\section{REFERENCES}

1. COLLINS, H. L.; KAUFMANN, S. H. E. The many faces of host responses to tuberculosis. Immunology, v. 103, n. 1, p. 1-9, 2001.

2. CORREIA, J. W. et al. Interleukin-6 blood levels in sensitive and multiresistant tuberculosis. Infection, v. 37, n. 2, p. 138-41, 2009.
3. DHEDA, K. et al. The immunology of tuberculosis: from bench to bedside. Respirology, v. 15, n. 3, p. 433-50, 2010.

4. DYE, C. et al. Global burden of tuberculosis. Estimated incidence, prevalence, and mortality by country.JAMA, v. 282, n. 7, p. 677-86, 1999.

5. DYE, C. et al. Evolution of tuberculosis control and prospects for reducing tuberculosis incidence, prevalence, and deaths globally. JAMA, v. 293, n. 22, p. 2767-75, 2005. 
6. GABAY, C.; KUSHNER, I. Acute-phase proteins and other systemic responses to inflammation. $N$ Engl J Med, v. 340, n. 6, p. 448-54, 1999.

7. KAUFMANN, S. H. How can immunology contribute to the control of tuberculosis? Nat Rev Immunol, v. 1, n. 1, p. 20-30, 2001.

8. LA CAVA, A.; SARVETNICK, N. The role of cytokines in autoimmunity. In: Genes and genetics of autoimmunity. La Jolia, CA (USA): Curr Dir Autoimmun, v. 1, 1999. p. 56-71.

9. LADEL, C. H.; SZALAY, G.; KAUFMANN, S. H. Interleukin-12 secretion by Mycobacterium tuberculosis - infected macrophages. Infect Immun, v. 65, n. 5, p. 1936-8, 1997.

10. LADEL, C. H. et al. Lethal tuberculosis in interleukin-6-deficient mutant mice. Infect Immun, v. 65, n. 11, p. 4843-9, 1997.

11. LALVANI, A. Diagnosing tuberculosis infection in the 21st century: new tools to tackle an old enemy. Chest, v. 131, n. 6, p. 1898-906, 2007.

12. MACK, U. et al. LTBI: latent tuberculosis infection or lasting immune responses to M. tuberculosis? A TBNET consensus statement. Eur Respir J, v. 33 , n. 5 , p. $956-73,2009$

13. MACMICKING, J. D. et al. Identification of nitric oxide synthase as a protective locus against tuberculosis. Proc Natl Acad Sci USA, v. 94, n. 10, p. 5243-8, 1997.

14. MINISTÉRIO DA SAÚDE (Brasil). Secretaria de Vigilância em Saúde. Departamento de Vigilância Epidemiológica. Manual de recomendações para o controle da tuberculose no Brasil. Brasília: Ministério da Saúde, 2011.

15. MINISTÉRIO DA SAÚDE, 2011. Série histórica da taxa de incidência de tuberculose. Brasil, regiões e unidades federadas de residência por ano de diagnóstico (1990 a 2010). Atualizado em 20 out. 2011. Disponível em: <http://portal.saude.gov.br/portal/arquivos/pdf/taxa_ incidencia_tuberculose_1990_2011_20_10_11.pdf>. Acesso em: 30 dez. 2011.

16. NAGABHUSHANAM, V. et al. Innate inhibition of adaptive immunity: Mycobacterium tuberculosis-induced IL-6 inhibits macrophage responses to IFN- $\lambda$.J Immunol, v. 171, n. 9, p. 4750-7, 2003.

17. PAPANICOLAO, D. A. et al. The pathophysiologic roles of interleukin-6 in human disease. Ann Intern Med, v. 128, n. 2, p. 127-37, 1998.

18. RICHELDI, L. An update on the diagnosis of tuberculosis infection. Am J Respir Crit Care Med, v. 174, n. 7, p. 736-42, 2006.

19. SAUNDERS, B. M. et al. Interleukin-6 induces early gamma interferon production in the infected lung but is not required for generation of specific immunity to Mycobacterium tuberculosis infection. Infection Immunity, v. 68, n. 6, p. 3322-6, 2000 .

20. SCHINDLER, R. et al. Correlations and interactions in the production of interleukin-6 (IL-6), IL-1, and tumor necrosis factor (TNF) in human blood mononuclear cells: IL-6 suppresses IL-1 and TNF. Blood, v. 75, n. 1, p. 40-7, 1990.

21. YOUNG, D. B.; GIDEON, H. P.; WILKINSON, R. J. Eliminating latent tuberculosis. Trends Microbiol, v. 17, n. 5, p. 183-8, 2009.

22. ZHANG, Y.; BROSER, M.; ROM, W. N. Activation of the interleukin-6 gene by Mycobacterium tuberculosis or lipopolysaccharide is mediated by nuclear factors NF-IL-6 and NF-kB. Proc Natl Acad Sci, v. 91, n. 6, p. 2225-9, 1994.

\section{MAILING ADDRESS}

